\title{
Literackie konstrukcje traumy kulturowej: ideologiczny wymiar 'kobiet w żałobie' w po- wieściach Roberta Edrica In Desolate Heaven oraz Jodie Shields The Crimson Portrait
}

Marzena Sokołowska-Paryż

TEKSTY DRUGIE 2018, NR 4, S. 56-71

DOI: $10.18318 /$ td.2018.4.4

$\mathbf{W}$ wierszu z 1962 roku brytyjski poeta i weteran II wojny światowej Vernon Scannell pisze, że gdy ktoś zaczyna mówić o wojnie, on natychmiast myśli o „wojnie nazywanej «wielką»” i oczami wyobraźni widzi „brzegi okopów / Spuchnięte od worków z piaskiem; bandoliery, hełmy/ [...] Deski, błoto i szczury"1. Brytyjską obsesję na punkcie okropności I wojny światowej doskonale oddaje też inny poeta generacji postpamięci, Peter Porter, który dość prowokacyjnie pisze, że nawet w czasach po Auschwitz temat śmierci na masową skalę przywołuje jeden „prześladujący” (ang. haunting) obraz: „Trzęsący się mężczyźni [...] / Parapet z worków z piaskiem od lewa do prawa"2.

1 V. Scannell The Great War, w: Poetry by Heart (http://www.poetrybyheart.org.uk/poems/the-great-war/). Autorem przekładów ze źródeł anglojęzycznych cytowanych w artykule jest Marek Paryż.

2 P. Porter Somme and Flanders, w: Australian Poetry Library (https:// www.poetrylibrary.edu.au/poets/porter-peter/somme-and-flanders-0287045).
Marzena Sokołowska-Paryż - dr hab., jest adiunktem w Instytucie Anglistyki UW. Jej obszar zainteresowań naukowych obejmuje reprezentacje pierwszej i drugiej wojny światowej w literaturze i filmie. Ostatnio opublikowała Reimagining the War Memorial, Reinterpreting the Great War: The Formats of British Commemorative Fiction (2012) oraz współredagowała The Great War in Post-Memory Literature and Film (2014). Kontakt: m.a.sokolowska-paryz@uw.edu.pl 
W brytyjskiej „pamięci kulturowej”3 złożona i wielowątkowa historia I wojny światowej została skutecznie zredukowana do wydarzeń z frontu zachodniego, konsekwentnie przestawianego jako miejsce bezsensownej rzezi i niewyobrażalnego cierpienia żołnierzy. Bezprecedensowa liczba ofiar wojny została wpisana w kulturową narrację straconego pokolenia ${ }^{4}$, ukształtowaną na kanwie poezji żołnierskiej (Wilfred Owen, Siegfried Sassoon, Herbert Read, Isaac Rosenberg), wspomnień weteranów wojennych (Robert Graves Goodbye to All That, Edmund Blunden Undertones of War) oraz powieści (A.P. Herbert The Secret Battle, Richard Aldington Death of a Hero), do dzisiaj skutecznie kultywowaną w literaturze (John Harris Covenant with Death, Pat Barker Regeneration, Sebastian Faulks Birdsong, Michael Morpurgo Private Peaceful) i filmie (Oh! What a Lovely War, reż. Richard Attenborough, King and Country, reż. Joseph Losey, The Trench, reż. Willliam Boyd).

Wspominając swoje podróże do miejsc pamięci we Francji i Belgii, brytyjski historyk Martin Gilbert opisuje szczególne wzruszenie, jakie odczuwał, gdy patrzył na wyryte na ścianach Tyne Cot Memorial nazwiska żołnierzy, których ciał nigdy nie odnaleziono, oraz na rozpościerające się przed nim nieskończone pole grobów: „Nawet przystrzyżone trawniki, starannie utrzymane klomby i pięćdziesięcioletnie drzewa nie mogły złagodzić szoku na widok tych wszystkich nazwisk i grobów"5. Można jednak założyć, że tak wyrażone emocje to nic innego jak reakcja zdeterminowana przez istniejący już kod kulturowy. Organizacja i estetyka cmentarzy wojennych, podobnie jak wygląd i lokalizacja miejsc pamięci, wynikały przede wszystkim z planu uczczenia ofiar:

Polityka pamięci wojny i upamiętnienia zawsze łączy się z żałobą i próbami zadośćuczynienia za fizyczne i psychologiczne cierpienie wojenne, i zawsze gdy ludzie podejmują działania żałobne albo reparacyjne, polityka wchodzi w grę. [...] Żałoba w społeczeństwie obywatelskim odbywa się w kontekście [...] „oficjalnych" założeń, które dotyczą tego, kto i jak zostanie upamiętniony. ${ }^{6}$

3 J. Assmann Pamięć kulturowa. Pismo, zapamiętywanie i polityczna tożsamość w cywilizacjach starożytnych, przeł. A. Kryczyńska-Pham, Wydawnictwa UW, Warszawa 2008.

4 Brytyjski mit "straconego pokolenia" został obszernie omówiony. Zob. R. Pound The Lost Generation, Constable, London 1964; R. Wohl The Generation of 1914, Harvard University Press, Cambridge, MA 1979.

5 M. Gilbert First World War, Harper Collins Publishers, London 1995, s. xvii.

6 T.G. Ashplant, G. Dawson, M. Roper The Politics of War Memory and Commemoration: Contexts, Structures and Dynamics: The Study of War Memories and Commemoration, w: The Politics of War 
Zatem Gilbert patrzy na nazwiska zaginionych i groby poległych przez pryzmat mitu straconego pokolenia, zgodnie z którym „w [I] wojnie [...] zginęli ludzie, którzy mogliby byli zapobiec międzywojennemu kryzysowi Wielkiej Brytanii jako światowej potęgi i stać się przywódcami, których w XX wieku zabrakło. [...] nazwiska zabitych [na pomnikach wojennych] to świadectwo ofiary całego pokolenia"'. Znamienne jest, że Gilbert nie myśli o rodzinach poległych żołnierzy, a przecież miejsca pamięci powstały dla tych, którzy przeżyli kataklizm. W kategoriach epistemologicznych śmierć zyskała prymat nad żałobą: „przez osiemdziesiąt lat historycy Wielkiej Wojny pomijali milczeniem rany, które po wojnie zostawił smutek. [...] Wydaje się, że historycy założyli, że wystarczy przytoczyć liczbę zabitych, aby oddać skalę katastrofy. Widzieli tę katastrofę w kontekście demograficznym, ale nie w równie ważnym kontekście zbiorowego smutku"8.

Utrwalenie archetypu żołnierza-ofiary zaowocowało marginalizacją wyobrażeń o kobiecym doświadczeniu wojny, nawet frontowym. Chociaż Mary Borden szokująco naturalistycznie opisała realia swojej pracy jako pielęgniarka w szpitalu polowym, a Evadne Price (pisząca pod pseudonimem Helen Zenna Smith) stworzyła udaną feministyczną wersję powieści Ericha Marii Remarque'a, w której bohaterami są kobiety kierujące ciężarówkami sanitarnymi, to ani The Forbidden Zone (1929) pierwszej autorki, ani Not So Quiet: Stepdaughters of War (1930) drugiej nigdy nie zyskały w kanonie literatury pierwszowojennej znaczenia porównywalnego do rangi twórczości weteranów wojennych. Nie dziwi brak zainteresowania literackimi ujęciami przeżyć społeczności cywilnej. Wydana w 1932 roku powieść The Ladies' Road pióra Pameli Hinkson pokazuje, jak emocjonalny i psychiczny ból po stracie ukochanych rujnuje życie bohaterek; ich samoalienacja symbolicznie wyraża rozpad wspólnoty. Książka Hinkson to wnikliwe studium żałoby przeżywanej w wymiarze osobistym i na płaszczyźnie społecznej, które jednakże nie miało szans, by zaistnieć na rynku czytelniczym opanowanym przez zołnierskie narracje o tragicznych doświadczeniach w okopach na froncie zachodnim. Można tu mówić o swoistej

Memory and Commemoration, ed. by T.G. Ashplant, G. Dawson, M. Roper, Routledge, LondonNew York 2000, s. 9.

7 G. Corrigan Mud, Blood and Poppycock: Britain and the First World War, Cassell Military Paperbacks, London 2004, S. 52.

8 S. Audoin-Rouzeau, A. Becker 14-18: Understanding the Great War, trans. C. Temerson, Hill and Wang, New York 2002, s. 174. 
„uzurpacji” cierpienia, a nawet o wynikającej stąd stygmatyzacji pisarstwa kobiecego:

Kobiety nie pisały o wojnie. Nie było ich na niej. Nie nosiły broni, co najwyżej kątem oka widziały krew i błoto pól bitewnych w bezpiecznych ścianach szpitala. [...] Pisały słabe wiersze o drugorzędnym rodzaju cierpienia, bo ich serca, umysły i ciała nie poznały bezpośrednio walki, oddzielał je bowiem od ogromu cierpienia parawan ochronny obowiązku i obyczaju. ${ }^{9}$

W wyniku umocnienia się takiej hierarchii doświadczeń wojennych ucierpiał temat żałoby, konwencjonalnie postrzeganej jak typowo kobiecy stan emocjonalny, niemogący się równać z ranami fizycznymi i psychicznymi (stres pourazowy) grożącymi żołnierzowi na polu walki.

Autorzy zarówno analiz historycznych, jak i opracowań literackich skłaniają się ku ścisłym rozróżnieniom genderowym: „większość współczesnych analiz skupia się niemal wyłącznie na męskich opisach [...] walki, są też analizy szczególnie dotyczące kobiet, ale wciąż brakuje [nie tylko] prób powiązania tych dwóch sfer doświadczeń"10, ale przede wszystkim analizy reprezentacji doświadczeń wojennych według transgenderowego klucza ideologicznych „[różnic] w pojmowaniu doświadczenia wojny"1.

Jak pisze Watson, do rangi paradygmatu urosła „opowieść [zogniskowana na] motywach wykorzystania i straty, niepotrzebnego poświęcenia, [oraz] masowej śmierci"12, temat obecny zarówno w prozie męskiej, jak i kobiecej w okresie międzywojennym. Po II wojnie światowej, w poholokaustowej rzeczywistości, ale też w obliczu kolejnych konfliktów militarnych, w Algierii, Wietnamie czy Bośni - aż po Irak i Afganistan, antywojenny wydźwięk książek o Wielkiej Wojnie wydawał się - i wydaje się nadal - zarówno politycznie, jak i etycznie, najwłaściwszy. Przewartościowania w literaturze postpamięciowej objawiają się przede wszystkim poszerzeniem wachlarza tematów, ale przesłanie pozostaje niezmienne, bez względu na genderowe

9 S. Ouditt Women Writers of the First World War: An Annotated Bibliography, Routledge, LondonNew York 2002, s. 1.

J.S.K. Watson Fighting Different Wars: Experience, Memory, and the First World War in Britain, Cambridge University Press, Cambridge 2006, s. 12.

11 Tamże, s. 12. 
niuanse autorstwa albo kreacje postaci. Przedstawienie odrębnych doświadczeń żołnierskich i cywilnych czy też męskich i kobiecych we współczesnej literaturze brytyjskiej służy w istocie jednemu celowi, tzn. ugruntowaniu poczucia traumy kulturowej. O tym rodzaju traumy mówimy wtedy, "gdy członkowie zbiorowości czują, że doświadczyli straszliwego wydarzenia, pozostawiającego nieusuwalne ślady na ich grupowej świadomości, na zawsze naznaczającego ich wspomnienia oraz zamieniającego ich przyszłą tożsamość w fundamentalny i nieodwołalny sposób"13. Jednak, jak wskazuje Jeffrey C. Alexander, status traumatyczny jest nadawany wydarzeniom tylko wtedy, kiedy ludzie wierzą, bowiem zostali do tego przekonani, że takie zjawiska w sposób nagły i bolesny wpłynęły na ich zbiorową tożsamość. Dla wyłonienia się traumy w sferze życia zbiorowego konieczne jest zatem, by kryzys społeczny przerodził się w kryzys kulturowy. Innymi słowy, trauma kulturowa pojawia się wtedy, gdy zostanie wykreowana. Zbiorowości same w sobie nie podejmują takich decyzji - robią to ich przedstawiciele, np. historycy czy pisarze ${ }^{14}$.

Schemat konstrukcji bohaterów w powieściach Jodie Shields The Crimson Portrtait i Roberta Edrica w In Desolate Heaven ilustruje wspomnianą już prawidłowość, że gender autora/autorki nie decyduje o ideologicznej wymowie utworu; bowiem oboje odzwierciedlają dominujący w literaturze angielskiej trend przedstawiania I wojny światowej jako kataklizmu dziejowego, który zdeterminował kolektywną narodową traumę, przechodzącą z pokolenie na pokolenie. Różnica między tymi powieściami a narracjami międzywojennymi (fikcyjnymi i autobiograficznymi) polega niemal wyłącznie na zmianie miejsca (lub miejsca i czasu) akcji (zamiast okopów i pola walki - angielski "front domowy" w The Crimsom Portrait i kurort szwajcarski po wojnie w In Desolate Heaven). Takie rozwiązanie pozwala wprowadzić do fabuły kobiety jako równorzędne z mężczyznami - w wymiarze psychologicznym - ofiary wojny. W obu powieściach pozafrontowe miejsce akcji służy uwiarygodnieniu tymczasowej więzi między kobietą w żałobie a żołnierzem po traumatycznych przejściach na wojnie, w ten sposób tworząc podstawę porównania cierpień bohaterki i bohatera.

Kai Erikson definiuje „traumę kolektywną” jako „rodzaj szoku, [...] stopniowe uświadomienie sobie, że wspólnota przestała istnieć jako efektywne

13 J.C. Alexander Trauma kulturowa i tożsamość zbiorowa, w: Znaczenia społeczne. Studia z socjologii kulturowej, przeł. S. Burdziej, J. Gądecki, Nomos, Kraków 2010, s. 195. 
źródło wsparcia i że ważna część jestestwa znikła"15. Powieści Shields i Edrica nie oddają prawdy historycznej, tylko "prawdę" ideologiczną; autorzy konstruują świat przedstawiony, który pokazuje, że I wojna światowa „zniszczyła podstawowe tkanki życia społecznego - więzi międzyludzkie i poczucie wspólnoty"16. Akcja powieści Shields rozgrywa się w 1915 roku, czyli przed bitwą nad Sommą (1916) i bitwą o Passchendaele (1917), które ze względu na olbrzymie straty armii brytyjskiej dostarczyły kanwy dla mitu straconego pokolenia i potwierdziły - w interpretacji historyków - bezsensowność wojny ${ }^{17}$.Zatem w powieści Shields to nie konkretna bitwa, ale sam fakt wojny powoduje nieodwracalne zmiany społeczne. Bohaterkę o imieniu Catherine poznajemy, gdy jej posiadłość jest w trakcie przekształcania w szpital dla rannych żołnierzy transportowanych z Francji i Flandrii. Z kolei bohaterka powieści Edrica, Elizabeth Mortlake, by ulżyć cierpieniu bratowej, zabiera ją do kurortu w Szwajcarii. Jest rok 1919; kiełkuje nadzieja, że skoro wojna dobiegła końca, uda się ukoić osobisty ból i rozpocząć życie od nowa. Podróż do Szwajcarii okazuje się jednak z góry skazaną na klęskę ucieczką od własnej zniszczonej wspólnoty do „nie-narodu”, przypadkowego zbiorowiska ludzi przegranych i wykluczonych, zranionych fizycznie i psychicznie ofiar i sprawców: „Nieprzenikniona otchłań kraju. Nieprzeniknione góry, nieprzeniknione serca, nieprzeniknione umysły. Kraj wydrążony ze wszystkiego, scalony jedynie uświęconą gotowością na przyjście czasu takiego jak ten. Zimna planeta w przegrzanym wszechświecie"18.

Chociaż to na skutek decyzji jej męża posiadłość rodowa została przekazana na potrzeby armii brytyjskiej, bohaterka powieści Shields postrzega przybycie personelu szpitalnego i napływ rannych jako znaki zawłaszczenia jej do niedawna własnej przestrzeni. Wojna znamionuje początek końca starego porządku; stabilny świat Catherine znika, gdy pojawiają się „obcy” (ang. strangers) ,",najeźdźcy” (ang.invaders), którzy, nie pytając nikogo o pozwolenie, rozstawiają sprzęt, przesuwają meble, depczą starannie wypielęgnowany

15 K. Erikson Notes on Trauma and Community, w: Trauma: Explorations in Memory, ed. by C. Caruth, The John Hopkins University Press, Baltimore-London 1995, s. 187.

Tamże, s. 187.

Zob. M. Gilbert First World War; ). Keegan The First World War, Hutchinson, London 1999; L. Macdonald Somme, Penguin Books, London 1993; L. Macdonald They Called it Passchendaele, Penguin Books, London 1993. 
ogród ${ }^{19}$. Wojna - uosabiania przez różnych „uzurpatorów” - zmienia porządek klasowy: „służący zaczynają zaniedbywać swoje obowiązki”" " „woźnice, majordomus, służący od butów i ubrań, od naprawiania sprzętów i utrzymywania porządku w korytarzach i pomieszczeniach dla służby zaciągnęli się do miejscowego batalionu”; „większość służących kobiet poszła do pracy $\mathrm{w}$ fabryce amunicji. Lepiej tam płacono, a ich czerwone dłonie stopniowo nabierały żółtawego odcienia od trującego TNT"21. Dopiero po odejściu tych anonimowych ludzi, na których dotąd nie zwracała uwagi, ponieważ nie byli tego godni, Catherine uzmysławia sobie, jak bardzo jest samotna.

W powieści Edrica w Szwajcarii przecinają się drogi przypadkowych ludzi, którzy chcą uciec od dawnego życia, zniszczonego przez wojnę. Z wyjątkiem jednego bohatera - brytyjskiego oficera oczekującego w szpitalu na sąd wojenny za niewykonanie rozkazu - wszyscy „uciekinierzy” ze starego świata nie mają przeszłości, ponieważ odniesienia do niej nie występują w narracji. Takie rozwiązanie skłania czytelnika do domysłów co do pochodzenia klasowego postaci, ale przede wszystkim dobitnie pokazuje, że brytyjscy, niemieccy czy włoscy goście uzdrowiska funkcjonują w mgławicowej powojennej teraźniejszości, w której nie ma miejsca na konwenanse oparte na wartościach minionego świata: „Kto potrafi zacząć żyć od nowa? Ci, których znany im świat zmienił w bestie albo w wyrzutków? Ci, którym zabrano wszystko, co posiadali?"22. Symbolicznym potwierdzeniem rozpadu porządku klasowego z jego wartościami moralnymi są konsekwencje osobliwego związku Elizabeth i Jamesona, handlującego pornografią, dzięki któremu kobieta poznaje ludzi ze sfer dotąd dla niej „nieistniejących” w sensie społecznym (klasa pracująca), kulturowym/etnicznym (Cyganie) i moralnym (niezamężne, ciężarne kobiety, którymi opiekują się zakonnice).

W obu powieściach bohaterki są świadkami „procesji” rannych, którzy wchodząc do przestrzeni cywilnej, wcześniej przed nimi zamkniętej, nieodwracalnie ją zmieniają, co jest kolejnym znakiem końca starego porządku. W The Crimson Portrait Catherine obserwuje, jak przyjeżdżają kolejni ranni; choć ich stan jest różny, w jej oczach zlewają się w masę: „niemi mężczyźni $\mathrm{w}$ jednakowych nakryciach albo w niebieskich szpitalnych marynarkach, 
okręceni bandażami jakby ich razem związano"23. Są zbiorowością „innych”, którzy nie tylko burzą jej dotychczasowy rytm życia, ale przede wszystkim poprzez swoją obecność naznaczają całe miejsce cierpieniem: „dom był [...] zbrukany, przeklęty" ${ }^{\prime 2}$. Wielu rannych to dosłownie ludzie bez twarzy, których obecność odbiera tożsamość głównej bohaterce; musi usunąć z domu lustra, co oznacza, że nie będzie już mogła patrzeć na siebie jak na osobę, którą kiedyś była. Gdy jej status i kobiecość tracą znaczenie, ponieważ w warunkach wojny liczy się tylko umiejętność niesienia pomocy rannym, stopniowo ulega też redukcji rola Catherine jako głównej bohaterki powieści. Na pierwszy plan wysuwa się natomiast rozbudowany wątek medyczny, opowiadający o osiągnięciach w zakresie rekonstrukcji twarzy. Niemniej jednak ideologicznie znaczenie Catherine jako przekaźnika traumy kulturowej znajduje odzwierciedlenie w wątku jej relacji z jednym z pacjentów.

W In Desolate Heaven - podobnie - Elizabeth zauważa porażający kształt pochodu rannych: najpierw pacjenci na wózkach, potem chodzący o kulach, na końcu niewidomi, lecz przede wszystkim czuje, że żołnierzy łączy ich inność, mająca fizyczne i psychiczne symptomy, która separuje ich od mieszkańców oraz gości szwajcarskiego kurortu, ale ma moc zarażania bólem. Elizabeth nie może oprzeć się wrażeniu „zimnego wiatru, który wraz z przemarszem nierównej kolumny mężczyzn i pielęgniarek wdarł się w ostatnie ciepłe i jasne dni"25. Właściciele kurortów chętnie pozbyliby się tych intruzów, gdyż ich cierpiętniczy wygląd odstrasza gości. Elizabeth wszakże, pod wpływem widoku rannych, stać na współczucie, ponieważ wie, przez co przeszli żołnierze: „Jej brat-pilot, mąż Marii, został oślepiony i żył w takim stanie przez sześć miesięcy, dopóki nie poddał się infekcji, wykarmionej na jego ranach i oparzeniach. Dlatego odczuwała rodzaj pokrewieństwa z tym mężczyznami i patrzyła na nich z bliska [... $]^{226}$.

Jest znamienne, że bohaterki obu omawianych powieści nurtuje zależność rannych żołnierzy od pielęgniarek. W większości młodzi mężczyźni potrzebują pomocy i ochrony kobiet. Opisy takich sytuacji wynikają z analogicznych zamysłów autorów, którzy wszakże nie kreują korespondujących ze sobą wątków po to, by unaocznić, że - jak pisała Sandra Gilbert - „wraz z postępującą

\footnotetext{
23 J. Shields The Crimson Portrait, s. 36. 
alienacją mężczyzn względem ich własnych przedwojennych jaźni, [...] kobiety rosły w siłę, jakby za sprawą jakiegoś niesamowitego zwrotu wahadła historii"27. Istotny jest fakt, że obrazy pochodów rannych żołnierzy, będące odwróceniem społecznie ukształtowanych ról genderowych, pojawiają się na początku powieści Shields i Edrica, co stwarza możliwość epistemologicznego zrównania traumy cywilnej (kobiecej) i żołnierskiej przy wykorzystaniu schematu „męskości w kryzysie”. Celem nie jest tu jednak feministyczna reinterpretacja Wielkiej Wojny, tylko wyrażenie ponadgenderowej kolektywnej (narodowej) traumy.

Więzi zawiązywane przez bohaterki i bohaterów obu powieści są tymczasowe, odpowiadają wymogom chwili, ale nie dają nadziei na odbudowę wspólnoty. Jak bowiem zakłada teoria traumy kolektywnej, „«Ja» wciąż istnieje, ale poraniony i zapewne zmieniony na zawsze. «Ty» wciąż istniejesz, ale odległy i poza polem kontaktu, który coś znaczy”, toteż ostatecznie „«My» już nie istniejemy jako [...] połączone komórki jakiegoś większego społecznego ciała"28. W The Crimson Portrait Catherine, nie mogąc się pogodzić ze śmiercią męża, wszędzie szuka śladów jego obecności, ale jej posiadłość, drastycznie odmieniona, staje się miejscem obcym i niepodobnym do domu, w który kiedyś mieszkała z ukochanym. Jak na ironię, właśnie w jednym z rannych, którzy zrazu wzbudzili jej irytację, Catherine niespodziewanie ujrzy „nie, nie Charlesa, ale przejaw jego bytności, która ożywiła obcego mężczyznę, żeby ona odczytała znak. Okrył tego człowieka jak rękawiczka, zbroja, czekająca pustka, którą obcy wypełnił"29. Wprawdzie iluzja musi pozostać iluzją, ale Catherine rozpoznaje w Julianie „pokrewnego ducha" ${ }^{\text {30 }}$, a ich szczególny związek, ukształtowany na zasadzie podobieństwa traumy, każe jej i jemu stworzyć siebie od nowa. W powieści Shields chirurgiczna rekonstrukcja twarzy jawi się jako (nieodzowna) konstrukcja nowej tożsamości. Wdowa podsuwa chirurgom-artystom zdjęcie poległego męża jako wzór dla nowej „twarzy” Juliana; zarazem im bardziej próbuje „wskrzesić” oblicze męża w twarzy przypadkowo spotkanego żołnierza, tym głębsza jej własna przemiana. Shields sugeruje analogię między okaleczonymi żołnierzami,

S.M. Gilbert, S. Gubar No Man's Land: The Place of the Woman Writer in the Twentieth Century, Vol. 2: Sexchanges, Yale University Press, Yale 1989, s. 425. 
„których wygląd ciągle się zmieniał, a tożsamość była płynna, nietrwała, niestała" ${ }^{31}$, a bohaterką, której osobowość także jest „płynna”: kobieta w żałobie pomaga w pracach nad odlewem twarzy rannych, co przygotowuje ją do pomagania innym, by w epilogu powieści stać się „zawodową asystentką pielęgniarki"32.

Emocjonalna więź między parą bohaterów In Desolate Heaven jest bardziej wieloznaczna, ponieważ ani on, ani ona nie przepracowali do końca osobistej traumy spowodowanej przeżyciami wojennymi w jego przypadku i stratą brata w jej przypadku. Bratowa głodzi się z rozpaczy po śmierci męża i dopiero jej wyjazd do Anglii pozwala Elizabeth zmierzyć się z własną żałobą: Po wyjeździe Mary Elizabeth pierwszy raz śni o bracie, młodym, przystojnym mężczyźnie, wykonującym akrobacje lotnicze. Po przebudzeniu bohaterka spogląda na fotografię sprzed czterech lat, na której są razem, szczęśliwi. Nie będąc zmuszona zważać na przytłaczające ją cierpienie bratowej, może wreszcie wypowiedzieć własny ból: „Opowiedziała mu o sobie. Poleciałaby z nim w podróż dokoła świata w ciepłej i cichej próżni, żeby tylko pozostać blisko niego i mieć pewność, że bezpiecznie do niej wróci"33.

Ideologiczną wymowę omawianych powieści potęguje swoiście patologiczny charakter żałoby kobiet; patologiczny, bo, jak napisała w klasycznej już pracy Elisabeth Kübler-Ross, ,żałoba to emocjonalna, duchowa i psychologiczna podróż do wyleczenia. Jeśli nie przepracujemy żałoby, tracimy szansę wyleczenia duszy, psychiki i serca"34. Według Kübler-Ross w psychologicznym procesie żałoby można wyróżnić pięć etapów: (1) zaprzeczenie (ang. denial), (2) gniew (ang. anger), (3) targowanie się (ang. bargaining), (4) depresja (ang. depression), oraz (5) akceptacja (ang. acceptance). Bohaterka Shields niewątpliwie uosabia przypadek uwięzienia w pierwszym stadium żałoby. Catherine ma świadomość śmierci męża, a żałobę "przywdziewa" jako „zbroję wdowy” (ang. a widow's armour)”35, żeby bronić się przed intruzami (ranni i personel szpitalny), którzy - jak ona to czuje - odebrali jej całe życie Catherine najpierw zatraca się w poszukiwaniu obecności (ducha?) męża.

31

Tamże, s. 83.

Tamże, s. 382.

Tamże, s. 367.

E. Kübler-Ross, D. Kessler On Grief and Grieving: Finding the Meaning of Grief Through the Five Stages of Loss, Simon \& Schuster, London-New York 2014, S. 227.

J. Shields The Crimson Portrait, s. 73. 
Zachowanie bohaterki powieści Shields potwierdza tezę Kübler-Ross, że „nie wiedząc, jak radzić sobie z bólem żałoby, unikamy go [...] i nie mamy przy tym świadomości, że w istocie próbujemy uniknąć bólu straty. [...] Unikając żałoby, odwracamy się od pomocy, jaką niesie żałoba, przedłużając ból”36. Chociaż opis pięciu etapów żałoby był wielokrotnie kwestionowany przez specjalistów z dziedziny psychiatrii ${ }^{37}$, to ramy teoretyczne stworzone przez Kübler-Ross są wciąż szeroko stosowane w badaniu kulturowych przedstawień żałoby. Catherine jest wszakże kreacją literacką, wehikułem przekazu dominującej "prawdy” ideologicznej o bezsensowności wojny, toteż Shields może odrzucić pozory psychologicznego, tudzież historycznego prawdopodobieństwa i wymyślić osobliwą drogę Catherine do fazy „akceptacji”, tym samym redefiniując samo pojęcie żałoby. Bezowocne poszukiwanie męża coraz bardziej ją frustruje, więc Catherine podejmuje próbę wskrzeszenia go fizycznie w osobie Juliana, zauważywszy jego podobieństwo do zmarłego. Tak zawiązuje się wątek zupełnie nieprawdopodobny: wymyślona postać podsuwa fotografię swojego męża fikcyjnej wersji postaci historycznej (Anne Coleman Ladd) jako wzór dla maski „zakrywającej” rany twarzy Juliana, by ten mógł odbudować swoją tożsamość. Ta maska będzie twarzą męża Catherine.

Postaci Catherine brakuje psychologicznej spójności; pojawia się ona i znika w wielowątkowej fabule, a gdy się pojawia, za każdym razem wydaje się kimś innym. Co kluczowe, jej kolejne przemiany mają coraz mniej wspólnego z osobistą żałobą. W powieści Shields występuje scena, w której Catherine podmienia fotografię Juliana na zdjęcie swojego męża, będąc zmuszona zniszczyć wszystkie inne fotografie Charlesa, aby nikt nigdy przypadkiem nie rozpoznał w masce Juliana zmarłego pana domu. Kobieta wrzuca zdjęcia do kominka - i w tym miejscu pojawia się słowo „gniew", przywodzące na myśl drugi z etapów żałoby opisanych przez Kübler-Ross:

Catherine owinęła się w marynarkę Charlesa z wielbłądziej wełny, przyzywając intymne poczucie jego ciała. Ale jej zmysły nie chciały poddać się jej życzeniu, jej skóra nie zapamiętała przyjemności, jaką dawał jej kiedyś mąż. [...] Maska Juliana. Płytka próżnia, do której mogła wlać swoją jaźń. Wystarczyło, że Catherine wypowie swoje prawo do niej. Jej

E. Kübler-Ross, D. Kessler On Grief and Grieving..., s. 229.

37 Zob. R. Davis Konigsberg The Truth About Grief: The Myth of Its Five Stages and the New Science of Loss, Simon and Schuster, New York-London-Toronto-Sydney 2011. 
gniew na Charlesa za to, że ją opuścił, zlał się w kształt trójkąta, które jeden wierzchołek wbił się w jej plecy niczym rzutka. Decyzja została podjęta. ${ }^{38}$

Spalenie fotografii to swoista ceremonia pogrzebowa, zatem próba odtworzenia jego podobizny w twarzy rannego żołnierzu nabiera innego znaczenia, niż sugerowałaby Kübler-Ross. Twarz zmarłego to „dar” dla Juliana: „Uważała, że po wojnie, kiedy wszystko na świecie się zmieni, nowa tożsamość będzie najlepszym sposobem na przetrwanie. Julian będzie nosił maskę - twarz Charlesa - i będą żyć ze sobą w wieczornym mroku. Ona ocaliła go, gdy zawiedli chirurdzy, a on nigdy nie odejdzie”"39. Ostatecznie więc etap „zaprzeczenia", przez który przechodzi bohaterka powieści Shields, ma przede wszystkim związek z niezgodą na utratę dawnego sposobu życia: Natomiast „złość", z której rodzi się pomysł na nową twarz Juliana, skierowana jest nie przeciwko mężowi, lecz przeciwko wojnie, „odpowiedzialnej za całe to zniszczenie" ${ }^{\text {40 }}$. Jednak Catherine odczuwa również poczucie winy. Kiedy nowa "twarz" Juliana zaczyna przypominać rysy jej męża, jest to dla bohaterki jedynie potwierdzenie nieosiągalności celu, który sobie postawiła: „Fałsz jego wyglądu zdradziło migotliwe światło świecy ${ }^{41}$. Catherine jako uosobienie „kobiety w żałobie” jest w istocie postacią o znaczeniu elegijnym; jej pogodzenie się z niemożnością odzyskania męża w osobie rannego żołnierza oznacza pogodzenie się z utratą świata bezpowrotnie minionego.

"Gaz, szok bombowy i rany twarzy” stanowią po dzień dzisiejszy „ikoniczne rany"Wielkiej Wojny ${ }^{42}$, a ich rola w narracjach kulturowych służy niezmiennie podkreślaniu barbarzyństwa konfliktów zbrojnych. Stąd u Shields niezwykle szczegółowy opis ran twarzy, wykorzystujący specjalistyczny język medyczny. Reakcja Catherine na proces „zakrywania” twarzy Juliana podobieństwem jej męża kieruje uwagę na skuteczność maski - w aspekcie medycznym, psychologicznym i etycznym - zamiast pogłębiać psychologiczny portret bohaterki. Jak pisze Suzannach Biernoff, „, publiczny spektakl okaleczonej twarzy także

38 J. Shields The Crimson Portrait, s. 264-265.

39 Tamże, s. 270.

40 Tamże.

41 Tamże, s. 356-357.

42 Zob. F.A. Reid Medicine in First World War Europe: Soldiers, Medics, Pacifists, Bloomsbury, London-Oxford-New York-New Delhi-Sydney 2017, s. 71-112. 
skutkował kryzysem przedstawienia, [...] ten rodzaj kryzysu zagrażał samej koncepcji natury ludzkiej w kontekście społecznego i ekonomicznego wstrząsu" ${ }^{\text {"3 }}$. Bez względu na starania, by maski jak najbardziej przypominały twarz żołnierza przed jej uszkodzeniem, efektu naturalności nigdy nie udało się uzyskaćc ${ }^{44}$. Samo założenie potrzeby maski tym mocniej podkreślało społecznie nieakceptowalną, "inność" rannych żołnierzy a odpychająca straszność ich wyglądu już w okresie międzywojennym została wykorzystana przez Ernsta Friedricha do stworzenia wstrząsającego przekazu antywojennego ${ }^{45}$. W swojej pacyfistycznej fotograficznej narracji Friedrich uwzględnił m.in. zdjęcia drastycznie okaleczonych żołnierzy pod znamiennym tytułem „twarze wojny”. Skupiając się na żołnierzach „bez twarzy”, Shields powiela ideologiczny schemat Friedricha, by tym dobitniej ukazać przerażające oblicze wojny. Ale tak jak maska miała zakryć to, czego społeczeństwo nie chciało widzieć - a i żołnierze często chcieli ukryć, bojąc się odrzucenia - tak też Shields wskazuje na inny (metaforyczny) rodzaj maski. Stéphane Audoin-Rouzeau i Annette Becker zauważają, że żałoba bywa okazywana albo zbyt ostentacyjnie, zamieniając się w spektakl, albo „psychiczne cierpienie po stracie na najbardziej intymnym poziomie [bywa] stłumione, ukryte, schowane, wyparte" ${ }^{16}$. W obu przypadkach mamy do czynienia z maską jako zasłonięciem prawdy cierpienia.W powieści Shields znajdziemy znamienną scenę, w której Catherine, będąc w Londynie, przenikliwie obserwuje pozory "normalnego" zachowania się kobiet, ich społecznie uwarunkowane maski: „Catherine odwróciła się od żołnierzy, żeby przyjrzeć się kobietom, czule utożsamiając je z wdowami. Jej siostry w żałobie. Czy też czuły wewnętrzną pustkę? Czy chodziły we śnie, otępiałe, zawieszone na pustym środku? Czy smutek zmienił ich poczucie ziemskiej wagi?" ${ }^{47}$.

W powieści Edrica stan bratowej głównej bohaterki, zgodnie ze współczesną terminologią, można uznać za depresję kliniczną ${ }^{48}$. Podobnie jednak jak w przypadku bohaterki powieści Shields, psychologiczny portret Mary ma

\section{S. Biernoff Portraits of Violence: War and the Aesthetics of Disfigurement, University of Michigan Press, Ann Arbor 2017, s. 60.}

44 J. Shields The Crimson Portrait, s. 315.

45 E. Friedrich Krieg dem Kriege, Zweitausendeins, Frankfurt am Main 1980, s. 204-227.

46 S. Audoin-Rouzeau, A. Becker, 14-18, s. 177.

47 J. Shields The Crimson Portrait, s. 131-132.

48 E. Kübler-Ross, D. Kessler On Grief and Grieving, s. 20. 
przede wszystkim cel ideologiczny. Postać wręcz literalne ilustruje objawy Freudowskiej melancholii, która

pod względem psychicznym wyróżnia się głębokim i bolesnym zniechęceniem, ustaniem zainteresowania światem zewnętrznym, utratą zdolności do kochania, zahamowaniem każdej sprawności i spadkiem samopoczucia, wyrażającym się w formie zarzutów i pretensji kierowanych pod własnym adresem, posuwającym się aż do obłędnego oczekiwania kary. ${ }^{49}$

Zmiana otoczenia nie przynosi jednak oczekiwanej poprawy zdrowia psychicznego, Mary nie może jeść i zamiast nabrać sił, traci je. Widząc, jak rozpacz dosłownie zabija bratową, Elizabeth zaczyna podejrzewać, że kobieta chce się zabić: „Dopuszczała myśl, że Mary rozmyślnie doprowadzała się do stanu choroby, ale nie rozumiała jej motywów, dlatego też wyobrażała sobie, że Mary sama z siebie przyjmuje karę za to, że nie potrafiła pogodzić się z konfuzją, niepewnością albo smutkiem, który wciąż odczuwała" ${ }^{50}$. Lekarz tylko potwierdzi obawy Elizabeth, że nikt nie może pomóc osobie dążącej do samounicestwienia: „chce się zagłodzić na śmierć [...] i dla niej samej, im wcześniej to nastąpi, tym lepiej"51.

Co istotne jednak, Edric nadaje Freudowskiej melancholii wymiar wręcz ekstremalnie cielesno-fizjologiczny, tym samym tworząc z niej odpowiednik żołnierskiego cierpienia. Portretuje kobiecą postać w żałobie, którą cierpienie wyniszcza tak, jak trujący gaz niszczy żołnierza w wierszu Owena Dulce et Decorum Est; podobnie też czytelnik jest zmuszony „widzieć" $i$,słyszeć” fizyczność ludzkiego cierpienia: „Skóra Mary była blada, [...] i widać było kształt jej żeber. Jej piersi były małe i płaskie. [...] i wstrząsnęło nią, jak mało ciała i żywotności zachowała Mary"52. Należałoby jednocześnie zwrócić uwagę na ideologicznie nacechowane podobieństwo między Mary a żołnierzem o nazwisku Mitchell. O sile cierpienia psychicznego każdego z nich mówi potrzeba autodestrukcji Mary doprowadza swoje ciało do skrajnego fizycznego wyniszczenia, Mitchell natomiast nieodwracalnie okalecza swoją twarz,

S. Freud Żałoba i melancholia, w: Psychologia nieświadomości, Dzieła, t. 8, przeł. R. Reszke, KR, Warszawa 2009, s. 147. 
a drastyczność czynów tych postaci świadczy o tym, że w uniwersum powojennym „świat ciemności nie ma granic" ${ }^{\text {s3. }}$.

„Opowieść o przeklętych i zdradzonych młodych ludziach ma siłę wymowy”, pisze Gail Braybon, „wybrzmiewa w niej cały pesymizm oceny stulecia i przekonanie, że wojna otworzyła nowy rozdział w historii nieludzkiego traktowania jednych przez drugich"54. Stwierdzenie Stéphane'a Audoin-Rouzeau i Annette Becker, że „niewiele można zrozumieć z XX wieku bez przyjrzenia się z bliska wielkiej tragedii, jaką ludzie przeżyli w latach 1914-1918 i później"55, akcentując temat żałoby w kontekście I wojny światowej, doskonale się wpisuje w ideologiczne ramy myślenia ukształtowane już w okresie międzywojennym. Powstaje pytanie, jakiemu celowi miałaby służyć taka interpretacja żałoby w wymiarze kolektywnym? Odpowiedź jest prosta - służy ona propagowaniu tego samego „mitu daremnego działania”, który zdominował literaturę o wojnie w latach 30. Opisywanie cywilnych doświadczeń wojennych przez pryzmat kolektywnej żałoby ma niewątpliwe na celu intensyfikację efektu traumy kulturowej, która to jest wyłącznie propagowaną - z powodów ideologicznych i etycznych - wersją przeszłości: "Jest to roszczenie do pewnego fundamentalnego urazu, okrzyk lamentu w obliczu przerażającej profanacji pewnych wartości związanych z sacrum, pewna opowieść o straszliwie destrukcyjnych procesach społecznych oraz żądanie emocjonalnego, instytucjonalnego i symbolicznego odszkodowania i rekonstrukcji"56. Można twierdzić, że oryginalność powieści takich jak In Desolate Heaven oraz The Crimson Portrait wynika z równoważności skutków wojny w wymiarze cywilnym i żołnierskim na płaszczyźnie strukturalnej. Problem polega na tym, że postacie pokroju Catherine i Mary nie reprezentują nowej jakości epistemologicznej, jedynie poszerzają spectrum przewidywalnych typów postaci, które nasuwają określoną interpretację I wojny światowej. Żołnierz bez twarzy, żołnierz opętany szaleństwem, żołnierz oczekujący na sąd wojenny - to bohaterowie wielu narracji literackich i filmowych, zaś kobieta ogarnięta patologiczną żałobą jest niejako dodatkiem, the Great War: Historians and the Impact of 1914-18, ed. by G. Braybon, Berghahn Books, New York and Oxford 2003, s. 87.

Tamże, s. 391.

G. Braybon Winners or Losers? Women's Symbolic Role in the War Story, w: Evidence, History and

S. Audoin-Rouzeau, A. Becker, 1914-18, s. 174.

J.C. Alexander Trauma kulturowa i tożsamość zbiorowa..., s. 205. 
jedynie wzmacniającym wymowę kulturowego obrazu Wielkiej Wojny jako doświadczenia traumatycznego w wymiarze kolektywnym.

\section{Abstract}

\section{Marzena Sokołowska-Paryż}

UNIVERSITY OF WARSAW

Literary Constructions of Cultural Trauma: Ideological Implications of the 'Woman in Grief' in Robert Edric's In Desolate Heaven (1997) and Jodie Shields's The Crimson Portrait (2008)

Trauma theories have proven an immensely influential framework in the humanities. However, contemporary fictional representations of the Great War all too often focus on soldiers or veterans as the traumatized victims. In epistemological terms, the trauma of war experience has generally been considered superior to civilian trauma, which is related to the grief of losing a beloved person at the front. Focusing on Robert Edric's In Desolate Heaven (1997) and Jodie Shields's The Crimson Portrait (2008), Sokołowska-Paryż examines the ideological implications of the literary constructions of the'woman in grief.' Here she draws on cultural trauma theories as well as psychological theories of mourning.

\section{Keywords}

The Great War, cultural trauma, grief, British literature 